\title{
Soil organic carbon (SOC) in selected sacred groves from Bhor region of western ghats, Maharashtra
}

\section{L.M. HANGARGE, D.K. KULKARNI, V.B. GAIKWAD AND D.M. MAHAJAN}

Article Chronicle :

Received:

17.10.2015;

Revised :

12.11.2015;

Accepted :

22.11.2015
ABSTRACT : Western ghats of Maharashtra represents several sacred groves. Sacred groves are ideal ecosystems of a particular geographical area and represents unique floristic and faunal composition. Sacred groves are often studied from floristic and faunal view point. Present attempt is based on soil organic carbon estimation from four selected sacred groves situated in Bhor region of Pune district. These are - Somjaichi Rai, Maulidevichi Rai, Nivaganjaichi Rai, and Umberjaichi Rai. Rai is a local term used for sacred grove. Soil organic carbon in each sacred grove varied depending on decomposition of leaf litter as well as amount of biomass. In Somjaichi Rai the amount of soil organic carbon was 66.25 tonnes/ha while in Maulidevichi Rai it was 65.88 tonnes/ha; whereas in Nivganjaichi Rai it was 138.67 tonnes/ha and in Umberjaichi Rai it was 101.12 tonnes /ha.

HOW TO CITE THIS ARTICLE : Hangarge, L.M., Kulkarni, D.K., Gaikwad, V.B. and Mahajan, D.M. (2015). Soil organic carbon (SOC) in selected sacred groves from Bhor region of western ghats, Maharashtra. Asian J. Environ. Sci.,10(2): 166-171.

Key Words :

Soil organic

carbon, Sacred

groves, Western

ghats, Bhor region

Author for correspondence :

\section{L.M. HANGARGE}

Department of

Chemistry, A.T. College,

BHOR (M.S.) INDIA

Email:

axmanmadhavhangarge

@ rediffmail.com

See end of the article for

Coopted authors' 